\title{
KILKA UWAG O POLSKICH REFERENDACH
}

Nie jest moim zamiarem podejmowanie po raz kolejny rozważań teoretycznych lub historycznych dotyczących demokracji, a zwłaszcza relacji zachodzących między demokracją pośrednią a bezpośrednią ${ }^{1}$. Mój cel jest inny. Pragnałbym przedstawić kilka tez odnoszących się do instytucji referendum, o której mowa w Konstytucji RP z 1997 r. Chodzić tu będzie głównie o trzy jej odmiany: referendum ogólnokrajowe z art. 125, referendum ogólnokrajowe, na mocy którego wyrazić można zgodę na ratyfikację umowy międzynarodowej, o jakiej mowa w art. 90 ust. 1 (art. 90 ust. 2 w zw. z art. 125), oraz referendum zatwierdzające zmiany w Konstytucji odnoszące się do jej rozdziałów I, II lub XII (art. 235 ust. 6). Sporadycznie tylko odnosić się będę do referendum lokalnego, o którym wspomina art. 170 Konstytucji. Pragnę także dodać, że artykuł ten zawiera kilka uwag i ocen, które można byłoby określić jako publicystyczne.

\section{II}

Referendum nie jest instytucja głęboko zakorzenioną w polskiej tradycji ustrojowej ${ }^{2}$. W okresie międzywojennym nie było ono znane ówczesnym konstytucjom. Referendum powojenne z 1946 r., jego przedmiot, sposób przepro-

${ }^{1}$ Historii i teorii demokracji bezpośredniej, w tym referendum, jako jednej z postaci tej demokracji, a także ich relacji z demokracją pośrednią poświęcono ogromną ilość dzieł w różnych językach. W tym miejscu podaję nieliczne ich przykłady. Zob. m.in.: Y. Papadopoulos, Démocratie directe, Economica, Paris 1998; M. Marczewska-Rytko, Idea demokracji bezpośredniej od okresu antycznego do czasów Internetu i globalizacji, w: eadem, A. K. Piasecki (red.), Demokracja bezpośrednia. Wymiar globalny i lokalny, Wyd. UMCS, Lublin 2010, s. 13-28; B. Węglarz, Referendum jako podstawowe narzędzie demokracji bezpośredniej - zagadnienia teoretyczne, w: M. Marczewska-Rytko, A. K. Piasecki (red.), op. cit., s. 29-40; M. Musiał-Krag, Referendum w państwach europejskich. Teoria, praktyka, perspektywy, Wyd. Marszałek, Toruń 2008, s. 25-94; F. Hamon, Le référendum. Etude comparative, LGDJ-Lextenso, Paris 2012, s. 35-56; E. Zieliński, Problemy teoretyczne i klasyfikacyjne referendum, w: E. Zieliński, I. Bokszczanin, J. Zieliński (red.), Referendum w państwach Europy, Wyd. UW, Warszawa 2003, s. 19-38; M. Qvortrup, The Politics of Participation. From Athens to E-democracy, Manchester Univerisity Press, Manchester-New York 2007; P. Krzywoszyński, Referendum: przyczynek do historii sporów o zakres demokracji bezpośredniej, „Czasopismo Prawno-Historyczne” 2008, z. 1, s. 23-46.

${ }^{2}$ Por. np. M. Marczewska-Rytko, Demokracja bezpośrednia w Polsce. Refleksje i uwagi, w: eadem (red.), Stan i perspektywy demokracji bezpośredniej w Polsce, Wyd. UMCS, Lublin 2010. W zdaniu otwierającym ten artykuł autorka stwierdza: „Demokracja bezpośrednia w Polsce nie cieszyła się ani nie cieszy szczególną estymą" (s. 25). 
wadzenia oraz ustalania wyników nie może być wpisane na listę demokratycznych dokonań politycznych. Miało zresztą charakter epizodyczny i nie pozostawiło po sobie trwałych następstw w obowiązującym w Polsce prawie konstytucyjnym. Po przerwie trwającej wiele dekad ${ }^{3}$, kolejne ogólnonarodowe referendum przeprowadzono 29 listopada $1987 \mathrm{r} .{ }^{4}$ na podstawie znowelizowanych 6 maja 1987 r. przepisów Konstytucji PRL z 1992 r. Postanowienie art. 2 tej Konstytucji deklarujace, że władzę sprawuje w państwie „lud pracujaccy [...] przez swych przedstawicieli wybieranych do Sejmu i rad narodowych", uzupełniony został o ust. 3 stwierdzający, iż jej sprawowanie „następuje także poprzez wyrażenie woli w drodze referendum".

Referendum z 29 listopada 1987 r. dotyczace przeprowadzania w kraju reform gospodarczych i politycznych, mimo że przebiegło przy stosunkowo wysokiej frekwencji (ok. 67\%) i dało wynik pozytywny (na dwa pytania odpowiedź na „tak” - ok. 66\% i 69\%), nie pozostawiło żadnych trwałych następstw. Dynamika wydarzeń polityczno-ustrojowych z przełomu 1989 i 1990 r. była tak gwałtowna, że uczyniła rezultaty tego referendum bezprzedmiotowymi.

Kolejne dwa referenda - jedno dotyczace tzw. powszechnego uwłaszczenia i drugie odnoszące się do niektórych kierunków wykorzystania majątku państwowego rozpisane na dzień 16 lutego 1996 r. nie dało wyniku wiążącego z powodu niedostatecznej frekwencji głosujących. Wyniosła ona ok. 32\%, choć uzyskano w każdym z nich zdecydowana przewagę odpowiedzi pozytywnych (ok. 93\% i 94\%). Następne referendum oparte na przepisach ustawy konstytucyjnej z 23 kwietnia 1992 r. o trybie przygotowania i uchwalania Konstytucji Rzeczypospolitej Polskiej przeprowadzone 25 maja 1997 r. i dotyczace zatwierdzenia przez Naród konstytucji przyjętej przez Zgromadzenie Narodowe w 2 kwietnia 1997 r., miało wynik pozytywny. Przy umiarkowanej frekwencji (ok. 43\%) odpowiedzi „tak” udzieliło ok. 52\% obywateli. W tym jednak przypadku wiążacy rezultat referendum nie zależał od tego, ilu uprawnionych do głosowania obywateli stawi się przy urnach. Ostatnie z referendów przeprowadzone w Polsce przed 2014 r. to referendum w sprawie wyrażenia zgody na ratyfikację przez Prezydenta RP umowy o przystapieniu Polski do Unii Europejskiej i przekazaniu na jej rzecz niektórych kompetencji organów władzy państwowej RP (art. 90 ust. 1 Konstytucji). Referendum to przeprowadzone 7 i 8 czerwca 2003 r. miało za podstawę już nowe uregulowania ustrojowe (art. 90 ust. 3 w zw. z art. 125 Konstytucji RP z 1997 r.). Referendum przy wymaganej frekwencji (ok. 59\%) przyniosło wynik pozytywny, ponieważ za wyrażeniem takiej zgody wypowiedziało się ok. 77\% ogółu głosujących.

W kolejnych latach podejmowano następne próby uruchomienia obejmujacych cały kraj procedur referendalnych ${ }^{5}$. Z wnioskami w tych sprawach wy-

${ }^{3}$ Por. P. Krzywoszyński, $Z$ dyskusji nad referendum w Polsce Ludowej, „Czasopismo Prawno-Historyczne" 2009, z. 1, s. 173-179.

${ }^{4}$ Wykaz referendów przeprowadzanych w Polsce od tego czasu, ich tematyki oraz wyników zawiera np. Zarys instytucji referendum jako formy demokracji bezpośredniej. Referenda ogólnokrajowe w Polsce. Opracowanie tematyczne OT-620, Kancelaria Senatu, maj 2013, s. 8 i n.

${ }^{5}$ Listę tych przedsięwzięć z lat 2007-2012 podaje: Zarys instytucji referendum, op. cit., s. 12 13. Było ich dziewięć, z tym że nie tylko Sejm nie wyrażał zgody na rozpisanie referendum, ale też Senat, gdy z zamiarem takim wystapił Prezydent RP. Ponadto wnioskodawcami referendów byli nie tylko obywatele, lecz także np. posłowie. 
stępowali głównie obywatele. Jednakże Sejm żadnego z nich nie zaakceptował. Potwierdza to tezę, że referendum przeprowadzane w ogólnonarodowej skali nie jest w Polsce instytucją często stosowaną ani ugruntowaną w praktyce ustrojowej.

\section{III}

Już ze stylizacji art. 2 ust. 3 Konstytucji PRL w brzmieniu nadanym jej w 1987 r. wynikało, że podstawową formą realizacji władzy ludu pozostaje forma przedstawicielska; bezpośrednie decydowanie przez lud (suwerena) w sprawach państwa ma natomiast charakter uzupełniający.

Następujące w kolejnych latach przeobrażenia ustrojowe, mimo że głębokie, nie wprowadziły zmian w relacji między dwiema formami demokracji. Nadal demokracja bezpośrednia i jej główny instrument - referendum zajmuje miejsce podrzędne w ramach instytucjonalnych mechanizmów realizacji woli suwerena, teraz już Narodu - wszystkich obywateli Rzeczypospolitej (art. 4 w zw. z art. 1 Konstytucji RP z 1997 r.). Bezpośrednie sprawowanie władzy wymienione jest $\mathrm{w}$ art. 4 ust. $2 \mathrm{w}$ drugiej kolejności, po jej sprawowaniu przez przedstawicieli Narodu. W postanowieniu, które o tym mówi, używa się słowa „lub” wiazzaceego nazwy dwóch form sprawowania władzy (,,przez swych przedstawicieli”, „bezpośrednio”), a nie słów „i” czy „oraz”. Oznacza to, jak sądzę, że ustrojodawca nie potraktował ich równorzędnie, lecz pierwszą z nich świadomie wysunął na czoło.

Pogląd, który tu wyrażam, nie wynika z językowej jedynie analizy art. 4 Konstytucji RP, ale z całokształtu jej unormowań odnoszących się do form sprawowania władzy publicznej, a zwłaszcza państwowej i instytucji ustrojowych, które je zapewniaja. Akt ten w sposób zdecydowany, szczegółowy i stosunkowo obszerny na pierwszym miejscu w porządku urządzeń ustrojowych stawia organy przedstawicielskie - Sejm i Senat, przekazując im władzę ustawodawczą wraz ze znaczną liczbą uprawnień władczych zastrzeżonych do ich wyłącznej kompetencji. Gdy chodzi o sprawowanie władzy publicznej w ramach terytorialnych wspólnot samorządowych, Konstytucja RP czyni podobnie, mając na uwadze ich organy stanowiące i wykonawcze, przy czym pierwsze z nich zawsze pochodzić mają z wyboru, zachowując charakter przedstawicielski (por. art. 169).

Nie wydaje się, aby było niezbędne udowadnianie, że priorytet w realizacji władzy zwierzchniej Narodu przyznany przez ustrojodawcę odpowiednim organom jako jego przedstawicielom jest rozwiązaniem racjonalnym. Nieracjonalne i niezmiernie trudne $\mathrm{w}$ realizacji byłoby przyjęcie przeciwstawnej koncepcji. Państwo kierowane wolą Narodu wyrażaną przede wszystkim w formach referendalnych byłoby wystawione na nieuniknione niebezpieczeństwa. Do największych zaliczyć trzeba techniczne trudności w podejmowaniu bardzo licznych i złożonych rzeczowo decyzji przez grono o niezbyt wysokich kompetencjach merytorycznych, koszt przeprowadzania takich operacji, powolność 
procesu decyzyjnego itp. ${ }^{6}$ Nigdzie zreszta instytucje demokracji bezpośredniej nie są wysuwane przed instytucje demokracji pośredniej.

W odróżnieniu jednak od rozwiązania przyjętego w 1987 r., obecne uregulowania konstytucyjne dotyczące instytucji demokracji bezpośredniej są o wiele bogatsze. $\mathrm{O}$ referendach, zasadach ich przeprowadzania i wynikach, jakie one przynosza, mówi kilka przepisów, w tym tak rozbudowany, jak art. 125 . Ponadto pojawia się też nowa postać tej demokracji, jaka jest obywatelska inicjatywa ustawodawcza, o której stanowi art. 118 ust. 2 Konstytucji RP. Łącznie instytucjonalne oprzyrządowanie demokracji bezpośredniej jest w Polsce stosunkowo obfite. A do uregulowań konstytucyjnych dodać trzeba unormowanie ustawowe takie głównie, jak ustawy: z 14 marca 2003 r. o referendum ogólnokrajowym ${ }^{7}$ oraz z 15 września 2000 r. o referendum lokalnym ${ }^{8}$.

\section{IV}

Gdy przyjrzeć się konstytucjom innych państw, sytuacja jest pod tym względem rozmaita. Można wyróżnić kilka typów uregulowań9 ${ }^{\text {. }}$

Po pierwsze, jak w Polsce, znajdujemy w konstytucjach generalną klauzulę powołującą się na ideę demokracji bezpośredniej. Tak rzecz ujmuje np. konstytucja Litwy z 1992 r. (art. 4), Federacji Rosyjskiej z 1993 r. (art. 3 ust. 2 i 3), Bułgarii z 1991 r. (art. 1 ust. 2), Francji z 1958 r. (art. 3). Niekiedy konstytucje posługują się innymi określeniami niż np. „bezpośrednie sprawowanie władzy". Tak czyni konstytucja Chorwacji z 1990 r., stanowiąc, że naród sprawuje władzę również „poprzez bezpośrednie głosowanie ludowe” (art. 1), lub Portugalii z 1976 r. wprowadzająca pojęcie „demokracja partycypacyj-

${ }^{6}$ Problem zalet i wad procedur referendalnych jest częstym tematem rozważań w literaturze. Zwięzły, ale - jak się zdaje - w miarę pełny ich katalog przedstawia opracowanie: Zarys instytucji referendum, op. cit., s. 14-15. Wśród argumentów świadczących na rzecz referendów wymienia się m.in.: referendum wzmacnia demokratyczną legitymację suwerena, umożliwia mu podejmowanie rozstrzygnięć w sprawach publicznych, przyczynia się do ograniczenia wszechwładzy parlamentu. Przeciw referendum przemawiają następujące argumenty: referendum osłabia szacunek obywateli dla rządów przedstawicielskich, jest czasochłonne i przedłuża procedury decyzyjne, wiąże się z nim możliwa podatność na manipulację słabo zorientowanego w sprawie elektoratu. G. Brunner nie bez racji stwierdza: „[...] regions without a democratic tradition, forms of direct democracy may be used as weapons in political struggles or to camuflage authoritarian dictatorships. Apparently, the results are dependent upon the prevailing political culture" (idem, Direct vs Representative Democracy w: A. Auer, M. Bützer, Direct Democracy. The Eastern and Central European Experience, Ashgate, Aldershot-Burlington-Singapore-Sydney 2001, s. 225). O pozytywnych i negatywnych stronach demokracji bezpośredniej w tym referendum zob. też: A. Gałkowska, S. Gałkowski, Albo bezpośrednia, albo pośrednia, w: M. Marczewska-Rytko (red.), Stan i perspektywy demokracji bezpośredniej we wspótczesnym świecie, Wyd. UMCS, Lublin 2011 s. 39-55; zob. też: W. Marxer, Z. T. Pallinger, Stabilizing or Destabilizing? Direct-Democratic Instruments in Different Political Systems, w: M. Sëtäla, T. Shiller (red.), Referendums and Representative Democracy. Responsiveness, Acountability and Deliberation, Routlege, New York 2013, s. 34-55.

7 Dz. U. 2003, Nr 57, poz. 507 ze zm. (dalej jako: ustawa o referendum).

8 Dz. U. 2000, Nr 88, poz. 985 ze zm.

9 Na ten temat zob. m.in.: S. Tierney, Constitutional Referendums. The Theory and Practice of Republican Deliberation, Oxford University Press, Oxford 2012. 
na” (art. 2). Konstytucja Węgier z 2011 r. uznaje z kolei, że naród sprawuje władzę bezpośrednio „w wyjątkowych przypadkach” (art. B ust. 4 w rozdziale pt. „Fundamenty”). Można chyba założyć, że zwrot „decyzje polityczne opierają się na woli obywateli wyrażonej w wolnym głosowaniu", który znajdujemy w konstytucji Czech z 1992 r. również nawiąuje do tej idei.

Po drugie, o referendum mowa w przepisach o wolnościach i prawach obywatelskich. Prawo udziału w referendum, obok prawa udziału w wyborach, należy do takiej właśnie kategorii. Tak rzecz ujmuje np. konstytucja Hiszpanii z 1978 r., uznając, że obywatele „mają prawo udziału w sprawach publicznych bezpośrednio”. O prawie tym wspomina również np. konstytucja Federacji Rosyjskiej (art. 32 ust. 1 i 2), Litwy (art. 33) oraz Bułgarii (art. 42).

Po trzecie, w konstytucjach znajdujemy szczegółowe wskazania odnośnie do przedmiotu referendum. Niekiedy dotyczy to zmiany konstytucji ${ }^{10}$, zwłaszcza gdy referendum ma charakter aktu zatwierdzajacego decyzje parlamentu. Uregulowanie takie zawiera np. konstytucja Japonii z 1946 r. (art. 96). W Szwajcarii (konstytucja z 1999 r.), która - jak wiadomo - jest państwem szeroko korzystającym z instytucji referendum w różnych sprawach ${ }^{11}$, głosowaniu referendalnemu poddaje się zmianę konstytucji kantonalnej (art. 51) i federalnej (art 140). Podobne uregulowania wprowadza konstytucja Hiszpanii (art. 167 ust. 3 i art. 168 ust. 3).

W pewnej części przypadków konstytucje wskazują inne sytuacje, w których przeprowadzenie referendum jest możliwe lub niezbędne. Tak np. konstytucja Czech (art. 10a) referendum uznaje za formę, w jakiej można wyrazić zgodę na ratyfikację umowy międzynarodowej przenoszącej niektóre kompetencje Republiki Czeskiej na organizację lub instytucję międzynarodowa. Ponadto konstytucja ta (art. 62 lit. 1) wprowadza referendum w sprawie przystapienia tego państwa do Unii Europejskiej. Z kolei konstytucja Islandii z 1944 r. (art. 11) przewiduje możliwość usunięcia z urzędu w drodze referendum prezydenta republiki.

Niektóre konstytucje zawierają obszerne katalogi spraw, które podlegać moga referendum albo są spod takiej procedury wyłączone. Tak jest np. w przypadku Portugalii (art. 115) i Szwajcarii. Konstytucja Szwajcarii zna ponadto dwa rodzaje referendów - obligatoryjne i fakultatywne i wskazuje, jakie materie objęte sa jednym, a jakie drugim jego rodzajem (art. 140 i 141). Ze swej strony ustawa o partiach politycznych, wyborach i referendach przyjęta w 2000 r. w Wielkiej Brytanii i wchodząca w skład miejscowych uregulowań ustrojowych ogranicza się do uznania, że referendum przeprowadzane na mocy ustawy parlamentu polega na udzieleniu odpowiedzi na jedno lub kilka pytań. Nie limituje to jego zakresu przedmiotowego (por. art. 101 ust. 2), lecz chroni, jak się zdaje, odwieczną w tym kraju tradycję suwerenności parlamentu ${ }^{12}$.

\footnotetext{
${ }^{10} \mathrm{Na}$ ten temat zob. m.in. S. Tierney, Constitutional Referendums. The Theory and Practice of Republican Deliberation, Oxford University Press, Oxford 2012.

${ }^{11}$ Demokracja bezpośrednia. Szwajcarska demokracja modelem dla XXI wieku?, praca zbiorowa, wstęp S. Geisbulhler, Semper, Warszawa 2011.

${ }^{12} \mathrm{Na}$ ten temat zob. m.in. P. Biskup, Instytucja referendum $w$ brytyjskiej praktyce konstytucyjnej, „Przegląd Sejmowy” 2007, nr 1 (78).
} 
Po czwarte, ważnym gatunkiem referendum, o jakim mowa w konstytucjach, jest to, w wyniku którego można uchwalić lub uchylić ustawę. Możliwość tę zna w pewnym zakresie konstytucja Francji (art. 11) oraz konstytucja Włoch z 1947 r. (art. 75) - referendum abrogacyjne. Jest to istotne postanowienie, ponieważ wkracza w domenę zastrzeżoną zwykle dla władzy ustawodawczej i (jak to bywało w przypadku Francji) wywoływać może wątpliwości, czy nie jest instrumentem pozwalajacym na umacnianie w państwie tendencji autorytarnych ${ }^{13}$.

Na tym tle podkreślić należy, po piąte, że konstytucje przekazują kompetencje do rozpisania referendum różnym organom państwa. Chodzi głównie o dwa z nich - głowę państwa (prezydenta) i parlament. Prezydent występuje w tej roli na mocy postanowień np. konstytucji Federacji Rosyjskiej (art. 84 pkt c), Francji (art. 11), Włoch (art. 87). Natomiast uprawnienie to należy do parlamentu np. Litwy (art. 67 ust. 3). W Chorwacji kompetencje w tej kwestii są podzielone i (w zależności od sprawy) należą do Izby Przedstawicielskiej (art. 80 i 87 ) oraz prezydenta (art. 87). Przekazanie uprawnienia do rozpisania referendum jedynie prezydentowi może się wiązać z ustanowieniem prezydenckiego lub półprezydenckiego ustroju państwowego; jeśli zaś uprawnienie należy wyłącznie do parlamentu - ustroju z jego silnie zaznaczająca się dominacją polityczną. Jest to jednak tylko hipoteza, którą zdaje się potwierdzać przypadek francuski i rosyjski, a przeczyć mu włoski.

Ponadto, po szóste, konstytucje określaja niekiedy wymogi formalne dotyczace przeprowadzanego referendum i jego prawne skutki. Tak np. konstytucja Węgier (art. 8 w dziale - „Referendum ogólnokrajowe”) przewiduje, że Zgromadzenie Krajowe zarządza referendum z inicjatywy co najmniej 200 tys. obywateli, może zaś je zarządzić z inicjatywy prezydenta, rządu lub 100 tys. obywateli. Ważny i rozstrzygający wynik referendum ogólnokrajowego wiąże to Zgromadzenie. Wynik jest ważny, jeśli ponad połowa głosujaccych oddała ważne głosy, i wiążący, gdy „ponad połowa głosujących udzieliła identycznej odpowiedzi na sformułowane w referendum pytanie”. Z drugiej zaś strony, konstytucja Finlandii z 1999 r. stanowi (par. 53), że referendum ma charakter konsultacyjny.

Rozwiązania dotyczące referendum ogólnokrajowego (i jego pochodnych) ujęte w Konstytucji RP z 1997 r. nie odbiegają w sposób znaczący od tych, które znajdujemy w konstytucjach innych państw demokratycznych. Mają one jednak swoje osobliwości i słabości.

Podstawowe znaczenie dla konstytucyjnego uregulowania dotyczącego referendum ma art. 125 Konstytucji RP. Jest to przepis, z którym wiąże się kilka istotnych pytań. Nawet jeśli nie uda się na nie w tym miejscu przekonująco odpowiedzieć, warto przynajmniej je postawić.

13 Por. Ł. Jakubiak, Referendum jako narzędzie polityki. Francuskie doświadczenia ustrojowe, Księgarnia Akademicka, Kraków 2012. Autor przypomina, że referenda w V Republice za czasów prezydentury Ch. de Gaulle’a nosiły silne zabarwienie plebiscytarne. Straciły ten charakter po jego odejściu (np. s. 257-258). 
Przepis ten odnosi się do trzech przynajmniej kwestii: merytorycznego zakresu referendum, zasad jego zarządzania, ustalania wyników i jego skutków o charakterze publicznoprawnym.

Artykuł 125 ust. 1 Konstytucji RP wyznacza zakres przedmiotowy referendum ogólnokrajowego. Ponieważ jednocześnie art. 90 ust. 3 i art. 235 ust. 6 również w tej kwestii się wypowiadaja, przyjać trzeba, że ich uregulowania wprowadzają szczególny rodzaj referendów, nieobjętych zakresem przedmiotowym art. 125 ust. 1. Przedmiotem referendum wedle tego przepisu moga być sprawy „o szczególnym znaczeniu dla państwa”. Założyć, jak sądzę, trzeba, że moga to być wyłącznie takie sprawy. Inne, choć być może ważne z jakiegoś punktu widzenia, nie mogą być rozstrzygane w głosowaniach referendalnych. Zwrot „szczególne znaczenie” ma charakter klauzuli generalnej, której rozumienie co do konkretnych przypadków zazwyczaj bywa sporne. Co więcej, sprawy, o których tu mowa, muszą mieć istotne znaczenie właśnie dla państwa. To, jak rozumieć pojęcie „państwo”, również może nie być oczywiste. Czy chodzi tu o zespół instytucji sprawujących władztwo publiczne, czy bardziej o zorganizowaną w państwo wspólnotę obywatelską? Jedno nie wyklucza zresztą drugiego.

Nie powinno jednak budzić wątpliwości, że przedmiotem referendum nie mogą być sprawy, które nie dotyczą państwa jako pewnej całości. Referenda odnoszące się do problemów dotykających jedynie pewną grupę (kategorię) obywateli lub terytoriów objętych władztwem państwowym nie należą do zakresu, o którym mowa w art. 125 ust. $1^{14}$. Mogą być one ewentualnie poddane referendum lokalnemu.

Spór wokół oceny danych spraw, o to, czy są one wystarczająco „istotne”, by stanowić przedmiot referendum, a także o to, czy rzeczywiście dotyczą państwa w podanych wyżej rozumieniach, ma w polskich realiach zazwyczaj podłoże polityczne. Linia podziału biegnie głównie między stronnictwami posiadającymi swoich reprezentantów w parlamencie. Walka o to, aby uznać dane sprawy za podlegające rozstrzygnięciu przez Naród w drodze referendum, jest wówczas powiązana $\mathrm{z}$ trwającym przez lata starciem między ugrupowaniami stanowiącymi sejmową podstawę aktualnego rządu a jego oponentami. Doprowadzenie do rozpisania referendum i uzyskanie w nim wyniku zgodnego $\mathrm{z}$ oczekiwaniami inicjatorów jest wpisane $\mathrm{w}$ dążenie do zmiany układu sił parlamentarnych i obalenia rządu. Tak było np. w przypadku sporu wokół tzw. referendum edukacyjnego, który rozgorzał na jesieni $2013 \mathrm{r}$.

Czy istnieje bezsporna lista spraw, które moga (a nawet powinny) być poddane rozstrzygnięciu w drodze referendum ogólnokrajowego? Odpowiedź na to

${ }^{14}$ Por. też opinię Lecha Garlickiego na temat dopuszczalnego przedmiotu referendum ogólnopolskiego. Komentarz do art. 125, w: Komentarz do Konstytucji Rzeczypospolitej Polskiej, Wyd. Sejmowe, Warszawa 2001, s. 5 i n. 
pytanie jest negatywna. Takiej listy nie ma. Co najwyżej mówić można o istnieniu listy negatywnej: listy spraw, które referendum nie podlegaja. Biorac pod uwagę postanowienia Konstytucji RP z 1997 r., stwierdzić trzeba, że nie moga być przedmiotem referendum z art. 125 zmiany, które by jej dotyczyły. Przywoływany już art. 235 Konstytucji RP wprowadza w tym względzie istotne wymogi formalne i ograniczenia zakresowe. Referendum konstytucyjne ma zatwierdzać zmiany dokonane przez Sejm i Senat w szczególnym trybie (art. 235 ust. 1-5). O jego przeprowadzenie wystapić moga jedynie podmioty uprawnione do wniesienia projektu tych zmian (por. art. 235 ust. 1). Może ono dotyczyć tylko takich zmian, które odnoszą się do rozdz. I, II i XII Konstytucji. Jeśli wymogi te zostaną spełnione, rozpisanie referendum jest obowiązkiem Marszałka Sejmu, a zmiana Konstytucji zostaje przyjęta, jeśli opowiedziała się za nią większość głosujących. Warto zwrócić uwagę, że warunek minimalnej frekwencji głosujących dla wiążącego wyniku referendum w tym przypadku nie obowiązuje. Jest to zgodne z tym, co było przyjęte w odniesieniu do referendum zatwierdzającego Konstytucję przeprowadzonego w $1997 \mathrm{r.}^{15}$

Mimo oczywistych, moim zdaniem, uregulowań konstytucyjnych pojawiały się w dyskursie publicznym głosy, by niektóre sprawy objęte unormowaniem konstytucyjnym poddać rozstrzygnięciom referendalnym ${ }^{16}$. Dotyczyło to w szczególności odstapienia od zasady proporcjonalności w wyborach sejmowych i wprowadzenia w ich miejsce zasady, że wybory te przeprowadzane sa zgodnie z zasadą większości w okręgach jednomandatowych. Te i inne propozycje (np. zniesienia parlamentarnego immunitetu formalnego, zmniejszenia liczby posłów i senatorów, czy likwidacji Senatu) nie mogą być przedmiotem referendum $\mathrm{z}$ art. 125.

Argument, że jest to konstytucyjnie niedopuszczalne, bywa niekiedy uznawany za nie do przyjęcia ze względu na zagwarantowane w Konstytucji suwerenne prawa Narodu. Zapomina się jednak, że Rzeczpospolita Polska jest państwem demokratycznym co prawda, ale zarazem prawnym (art. 2 Konstytucji), a organy władzy publicznej działać muszą na podstawie i w granicach prawa (art. 7). Gdyby zatem np. Sejm podją uchwałę o rozpisaniu referendum, które konstytucyjnie nie jest dopuszczalne, naruszyłby zasadę legalizmu.

Ustawa o referendum w art. 63 ust. 1 wprowadza pewne dalsze ograniczenia. Referendum ogólnonarodowe nie może dotyczyć: wydatków i dochodów państwa, w szczególności podatków i innych danin publicznych, obronności państwa i amnestii. Lecz ograniczenia te odnoszą się jedynie do referendum przeprowadzanego z inicjatywy obywateli. Gdy więc ma to być referendum oparte na inicjatywie Senatu lub Rady Ministrów (art. 61), a także referendum zarządzone przez Prezydenta RP za zgodą Senatu, ograniczenia te nie wchodza $\mathrm{w}$ rachubę. Mają on zatem charakter względny.

Natomiast od strony pozytywnej brak unormowań prawnych odnoszacych się do przedmiotu referendum. Nie znane jest też w Polsce ogólnokrajowe

${ }^{15}$ Zob. S. Tierney, op. cit. Książka zawiera obszerny wykaz referendów przeprowadzanych w wielu krajach świata w latach 1898-2011.

${ }^{16}$ Pisałem o tym w artykule: Konstytucja nie przez referendum, „Rzeczpospolita” nr 246/2004. 
referendum obligatoryjne we wskazanych w Konstytucji lub innych aktach normatywnych przypadkach. Sytuację, o jakiej stanowi art. 235 ust. 6, jako wyjątkowa, w tym miejscu pomijam.

Czy zatem należałoby wprowadzić takie unormowania? Bez zmiany Konstytucji RP byłoby to niedopuszczalne. Można, moim zdaniem, pomyśleć o czymś innym. By ograniczyć i zracjonalizować polityczne spory o sprawy, które uznaje się za godne rozstrzygnięcia w trybie referendum ogólnonarodowego, warto poddać klauzulę generalną zawartą w art. 125 ust. 1 pogłębionej analizie na wzór tej, jakiej w swoim czasie Trybunał Konstytucyjny poddał klauzulę państwa prawnego ${ }^{17}$. Byłoby to zadanie nie tylko dla konstytucjonalistów, ale i specjalistów innych dziedzin (np. politologów), a także praktyków polityki. W wyniku takiej analizy powstać by mogły dwie listy spraw: tych, których w żadnym razie poddawać referendum się nie powinno, i tych, które mogłyby (a może nawet powinny) w referendum być rozstrzygane. Żadna $\mathrm{z}$ tych list nie mogłaby być traktowana jako zawierająca postanowienia o charakterze wiażaccym - czy to prawnie, czy politycznie, lecz jako luźna wskazówka pozwalająca łatwiej podjąć odpowiednią decyzję. Czy sporządzenie takiej listy skończyłoby się powodzeniem, nie wiem. Sądzę jednak, że zadania takiego warto się podjąć.

\section{VII}

Artykuł 125 ust. 2 Konstytucji RP stanowi, że referendum może zarządzić Sejm bezwzględną większością głosów w obecności co najmniej połowy ogólnej liczby posłów. Z kolei art. 63 ust. 1 ustawy o referendum precyzuje, że uchwała Sejmu w sprawie jego zarządzenia może zapaść na wniosek co najmniej 500 tys. osób mających prawo udziału w głosowaniu referendalnym. Obok art. 118 ust. 2 Konstytucji przyznającego grupie 100 tys. obywateli prawo inicjatywy ustawodawczej, przepis ten doprecyzowuje postanowienia odnoszące się do partycypacyjnych praw obywateli (por. art. 60-63 Konstytucji). Jednakże zarówno art. 125 ust. 2 Konstytucji, jak i art. 63 ust. 1 ustawy o referendum uznaja, że Sejm może (a więc nie ma obowiązku) je zarządzić w określonych przez art. 125 ust. 1 Konstytucji przypadkach. Jeszcze raz podkreślić więc trzeba, że w naszym porządku ustrojowym referenda ogólnokrajowe w sprawach o szczególnym znaczeniu dla państwa mają zawsze charakter fakultatywny.

$\mathrm{Na}$ tym tle pojawił się w ostatnich latach postulat, aby niektóre referenda inicjowane przez obywateli uczynić obligatoryjnymi ${ }^{18}$. Chodzić by miało o sytuacje, w których liczba podpisów pod wnioskiem o referendum jest bardzo znaczna, np. osiaga lub przekracza milion. Wówczas albo Sejm miałby obowiązek rozpisać referendum, albo zarządzenie o jego przeprowadzeniu wyda-

${ }^{17}$ Szeroko na ten temat: J. Oniszczuk, Państwo prawne w orzecznictwie Trybunału Konstytucyjnego (zasady państwa prawnego), Warszawa 1996.

${ }_{18}$ Pisałem o tym w artykule: Bezpośrednia kontra pośrednia, „Gazeta Wyborcza” z 28 czerwca 2013 r. 
wałby inny organ, ale zawsze w wykonaniu obowiązku prawnego. Narzuca się przypuszczenie, że pomysł ten inspirowany jest przez rozwiązanie przyjęte w konstytucji Węgier z 2011 r. (art. 8 - zob. wyżej). Wprowadzenie referendum obligatoryjnego w przypadkach objętych art. 125 ust. 1 Konstytucji RP oznaczałoby, że kwestia przedmiotu referendum nie będzie poddana ocenie. Każda sprawa musiałaby stać się przedmiotem referendum, jeśli znalazłaby uznanie w oczach odpowiednio wielkiej liczby obywateli.

Argumentem przemawiającym za tak pomyślanym referendum obligatoryjnym jest, że fakt zebrania pod wnioskiem o przeprowadzenie referendum wielkiej liczby podpisów jest dowodem na rzecz tezy, że w ten sposób Naród-suweren wyraził swą wolę, a jego przedstawiciel - Sejm nie ma prawa woli tej się przeciwstawić bez naruszenia art. 4 ust. 1 Konstytucji RP. Można zatem powiedzieć, że przez takie postawienie sprawy bliscy jesteśmy idei: „Vox Populi, vox Dei" ${ }^{\prime \prime}$.

Czy jednak sama liczba podpisów, jaką wylegitymować się muszą inicjatorzy wniosku referendalnego, przesądza o jego merytorycznej trafności? Może się przecież zdarzyć, że szerokie poparcie uzyskają inicjatywy, których realizacja naruszyłaby postanowienia Konstytucji przez ingerencję w jej treść. Gdyby wynik referendum był tego rodzaju, że treść tę trzeba by zmienić, zmiana taka dokonałaby się z pogwałceniem art. 235 Ustawy zasadniczej. Ponadto wziąć należy pod uwagę, że procedury referendalne i plebiscytarne wystawione sa na poważne niebezpieczeństwo populizmu. Nie jest więc wykluczone, że przedmiotem referendum stałyby się sprawy, które w publicznym poczuciu wymagają rozstrzygnięcia $\mathrm{w}$ określony sposób, mimo że rozstrzygnięcie to byłoby niekorzystne z punktu widzenia interesów państwa lub jego obywateli.

$\mathrm{Z}$ tych przynajmniej względów nie sądzę, aby rezygnacja $\mathrm{z}$ oceny wniosku referendalnego (nie tylko zreszta obywatelskiego) dokonywana z punktu widzenia kryteriów zawartych w art. 125 ust. 1 Konstytucji RP była dobrym pomysłem. Ale jeszcze raz zmuszony jestem podkreślić, że ocena taka, jeśli nie ma być motywowana względami politycznymi (o których wyżej wspominałem), powinna być oparta na bardziej doprecyzowanych niż obecnie przesłankach.

Można się zastanawiać, kto powinien dokonywać takich ocen i podejmować decyzję w tej sprawie. Czy ma to czynić, jak obecnie, Sejm, ciało ze swej natury mocno politycznie podzielone, czy inny organ? Oddanie prawa decyzji Sejmowi o tyle jest właściwe, że jest to organ uczestniczacy w realizacji suwerennych praw Narodu. Decyzje podjęte w referendum mogą rolę Sejmu w tej dziedzinie ograniczyć. Ale Sejm jest w pewnym stopniu sędzią we własnej sprawie, wobec tego jego decyzje o rozpisaniu lub odmowie rozpisania referendum z inicjatywy obywateli powinny być poddane kontroli organu wobec Sejmu zewnętrznego. Narzuca się myśl, że mógłby to być Trybunał Konstytucyjny ${ }^{20}$. Mógłby on też badać zgodność decyzji podjętej w referendum z Konstytucją. Lecz przyjęcie

${ }^{19}$ O „sakralizacji” decyzji ludu zob. M. Fatin-Rouge Stéfanini, Le contrôle du référendum par la justice constitutionnelle, Economica, Aix-en-Provence - Paris 2004, s. 43.

${ }^{20}$ Kontrola konstytucyjności referendum jest w świecie znana (np. we Francji i we Włoszech). Zob. na ten temat: F. Hamon, op. cit., s. 49 i n. 
takiego rozwiązania wymagałoby jej zmiany (głównie art. 188). Propozycja ta musi więc pozostać obecnie w zawieszeniu.

W każdym razie nie wydaje mi się słuszne, aby wprowadzić referendum obligatoryjne przeprowadzane $\mathrm{z}$ inicjatywy obywateli, i to niezależnie od tego, jak wielu z nich inicjatywę tę poprze swoim podpisem.

\section{VIII}

Pamiętamy, że jeśli w referendum ogólnokrajowym wzięła udział więcej niż połowa uprawnionych do głosowania, wynik referendum jest wiążący ${ }^{21}$. Rozstrzygnięcie zaś w referendum następuje, w zależności od sposobu postawienia pytań, albo przez to, że większość głosujących odpowie na zadane pytanie pozytywnie lub negatywnie, albo na jeden z zaproponowanych wariantów rozwiązań w sprawie poddanej pod głosowanie oddano najwięcej ważnych głosów (art. 66 ust. 2 ustawy o referendum). W każdym razie nie wymaga się w tym przypadku większości bezwzględnej - ustalanej w odniesieniu do ogółu uprawnionych ani większości kwalifikowanej. Powstaje jednak pytanie, co i dla kogo oznacza wiążący wynik referendum. Czy jest on wiążący dla uczestników głosowania, czy też, i w jakim sensie, dla innych podmiotów prawa?

Dla uczestników głosowania, a także dla wszystkich pozostałych obywateli jest on w tym sensie wiążący, że nie może być podważany w żadnej procedurze odwoławczej. Można co prawda wystapić z protestem przeciw ważności referendum z powodów, o których mowa w ustawie (art. 33-36 ustawy o referendum), ale jeżeli Sąd Najwyższy nie podejmie uchwały w sprawie unieważnienia głosowania w obwodach i nie zarządzi jego powtórzenia, to referendum uznaje się za ważne. Skuteczne podważenie ważności referendum w skali całego kraju musi skutkować uznaniem go za niewiążące. Obywatele powinni zatem podporządkować się wynikom referendum, choć nie ma przeszkód, aby w późniejszym czasie przy okazji przeprowadzania referendum w tej samej sprawie zmienili zdanie i odpowiedzieli na postawione pytanie(-a) w odmienny sposób niż poprzednio.

Dyskusyjne jest, czy wiążący wynik referendum ogólnokrajowego prowadzi w sposób bezpośredni i samoistny do nałożenia na obywateli jakichś obowiązków lub nadania im praw. W moim przekonaniu referendum skutków takich nie przynosi. Nie ustanawia ono wprost też jakichś unormowań prawnych. Uwagi tej nie można odnieść jednak do referendum w sprawie wyrażenia zgody na ratyfikację umowy międzynarodowej, o której stanowi art. 90 Konstytucji RP, ani do zatwierdzenia zmian obejmujących tekst Konstytucji, we fragmentach, do których odnosi się art. 235 ust. 6 . W tym przypadku skutki prawne pojawiają się już w wyniku przeprowadzenia referendum ważnego i po uzyskaniu w nim rozstrzygnięcia wiążącego. Natomiast we wszystkich

${ }^{21} \mathrm{O}$ następstwach wiążącego referendum ogólnokrajowego zob. M. Jabłoński, Referendum ogólnokrajowe w polskim prawie konstytucyjnym, Wyd. UWr, Wrocław 2011, s. 103-112. 
innych przypadkach, z jakimi związana jest procedura referendalna z art 125 Konstytucji RP, sytuacja jest odmienna.

Tak więc wiążące referendum daje odpowiedź na postawione w nim pytanie(-a), ale odpowiedź ta nie jest równoznaczna z podjęciem decyzji prawotwórczej lub ustanawiającej jakieś stosunki prawne między wskazanymi $\mathrm{w}$ niej podmiotami (np. administracyjnoprawne czy cywilnoprawne). Ponad wszelką wątpliwość wiążący wynik referendum nie może zastapić wyroku sądowego w jakiejkolwiek sprawie. Reguła jest, że realizacja postanowienia podjętego w trybie referendalnym wymaga dalszych działań, głównie legislacyjnych. Gdyby więc np. sprawą poddaną rozstrzygnięciu referendalnemu była odpowiedź na pytanie: osiagnięcie jakiego wieku uprawnia do przejścia na emeryturę, i okazałoby się, że ma to być wiek inny od dotychczasowego, to $\mathrm{w}$ rezultacie takiego rozstrzygnięcia należałoby dokonać zmian w obowiąujacym prawie, przede wszystkim rangi ustawowej. Musiałby zatem powstać projekt odpowiedniej ustawy i winien on być wniesiony do Sejmu przez uprawniony podmiot. Mógłby być nim każdy z podmiotów dysponujacy inicjatywa ustawodawcza, o czym stanowi art. 118 ust. 1 i 2 Konstytucji RP.

Czy jednak, mając na uwadze wiążący wynik referendum, na wszystkich tych podmiotach ciążyłby w jednakowym stopniu obowiązek opracowania stosownej ustawy i wniesienia jej do Sejmu? Nie sądzę. Z całą pewnością nie dotyczyłby on obywateli. Trudno bowiem wymagać od amorficznej, niezorganizowanej zbiorowości osób fizycznych, aby realizowała tego typu obowiązek. Gdy idzie o posłów, sytuacja jest, moim zdaniem, nieco inna. Można byłoby oczekiwać, że jakaś ich grupa wystapi ze stosowną inicjatywą ustawodawczą. Jest to jednak oczekiwanie, które może mieć jedynie charakter polityczny. Jeśli za udzieleniem w referendum pozytywnej odpowiedzi, która stała się zarazem rozstrzygnięciem danej sprawy, opowiadała się np. jakaś frakcja parlamentarna mająca w swoich szeregach dostateczną liczbę posłów, by skorzystać z przysługujaccej im inicjatywy ustawodawczej, to takie oczekiwanie jest zasadne. Nie ma ono wszakże ugruntowania w obowiązującym prawie.

Więcej wymagać należy od pozostałych podmiotów dysponujących inicjatywą ustawodawczą - Prezydenta RP, Senatu i Rady Ministrów. To ich przede wszystkim wiąże prawnie wynik referendum. Taki wniosek wyprowadzić trzeba z art. 67 ustawy o referendum, który stwierdza, że „właściwe organy państwowe” podejmują niezwłocznie czynności w celu realizacji wiążącego wyniku referendum przez wydanie aktów normatywnych bądź podjęcie innych decyzji.

Projekt ustawy realizujacej ten wynik powinien być wniesiony przez ten przede wszystkim podmiot, do którego konstytucyjnych zadań i kompetencji należy podejmowanie w sposób prawem przewidziany danego rodzaju spraw. Gdy chodzi o Senat, trudno mu jednak przypisać wyłączne kompetencje w tym względzie. Ma on prawo i obowiązek wypowiadać się we wszystkich sprawach objętych uregulowaniami ustawowymi. Stąd mógłby on występować z inicjatywą w każdej sprawie. Co się tyczy Prezydenta RP, ze względu na to, że przedmiotowy zakres jego zadań jest konstytucyjnie ograniczony (por. art. 126 
ust. 1 i 2) oczekiwać by należało, że będzie korzystał z inicjatywy ustawodawczej o tyle, o ile dana sprawa należy to tego właśnie zakresu, a także gdy sam był inicjatorem referendum w tej sprawie.

Jednakże przygotowanie i wniesienie projektu ustawy wykonującej decyzję podjęta w referendum jest głównie obowiązkiem Rady Ministrów, albowiem do niej należy prowadzenie wewnętrznej i zagranicznej polityki państwa (art. 146 ust. 1-3 Konstytucji RP) i realizacja kompetencji ujętych w art. 146.

Bardzo istotnym pytaniem jest, jakie następstwa mieć może niepodjęcie czynności zmierzających do realizacji wiążącego wyniku referendum mimo upływu terminu, o jakim mowa w art. 67 ustawy o referendum. Czy i jakie negatywne skutki wywoła to w odniesieniu do podmiotów, o których wyżej mowa? Co do obywateli, żadnych takich skutków oczekiwać nie należy. Nie są oni wszakże „właściwymi organami państwa” w jakimkolwiek rozumieniu tego zwrotu.

W odniesieniu do Senatu można co najwyżej mówić o skutkach politycznych ujawniających się w postaci negatywnych społecznych ocen jego działalności. To samo da się powiedzieć o posłach. Jak wiadomo, nawet największe ich zaniedbania polegające na zaniechaniu korzystania z inicjatywy ustawodawczej nie moga pociagać za sobą odpowiedzialności prawnej. Sa oni nieodwoływalni, nie można ich z tego powodu pozbawić immunitetu parlamentarnego, postawić przed sądem karnym czy Trybunałem Stanu. Można liczyć jedynie, że w przypadku ponownego kandydowania do Sejmu nie zostana przez obywateli wybrani. Ale jeśli zostaną wybrani, nie poniosą osobistej odpowiedzialności politycznej za brak pozytywnej reakcji na wiążaccy wynik referendum. Senat, jako ciało zbiorowe, również wyjęte zostaje w takim przypadku spod odpowiedzialności prawnej.

Można ewentualnie odpowiedzialności tej poddać Prezydenta RP. Byłaby to odpowiedzialność konstytucyjna przed Trybunałem Stanu, ale trzeba udowodnić, że brak jego aktywności, gdy idzie o wykonanie pozytywnej decyzji podjętej w referendum, był zamierzony, a sprawa, której ono dotyczyło, mieści się w zakresie jego zadań.

$\mathrm{W}$ istocie jedynym podmiotem, który można byłoby ścigać z tego tytułu z użyciem środków prawnych, jest Rada Ministrów. Środkami takimi moga być konstruktywne wotum nieufności (o co bardzo trudno) lub odmowa wotum zaufania (o co również niełatwo). Natomiast w drodze odpowiedzialności indywidualnej przed Trybunałem Stanu można byłoby ewentualnie karać Prezesa Rady Ministrów i/lub ministrów, którym dałoby się przypisać winę za powstałe zaniedbanie.

Sięgnięcie jednak po jakąkolwiek formę odpowiedzialności - politycznej czy prawnej, mało zresztą prawdopodobne, okazać się może bezskuteczne jako środek zapewniający wykonanie przez właściwy podmiot ciążącego na nim obowiązku. Jeśli zabraknie w tym względzie woli politycznej, akt referendalny pozostanie bez oczekiwanych następstw.

To samo da się powiedzieć o wiążącym wyniku referendum, gdy jest to wynik negatywny. Jeżeli wbrew niemu zostana - wcześniej czy później - uru- 
chomione procedury prowadzące do podjęcia decyzji niezgodnej z tym wynikiem, odpowiedzialność za taki stan rzeczy może się nigdy nie urzeczywistnić, a decyzja ta zostać podjęta.

Z drugiej strony negatywny, wiążacy wynik referendum może również oznaczać konieczność podjęcia przedsięwzięć legislacyjnych. Gdyby np. chodzić miało o to, czy należy pozostawić bez zmian obecne uregulowania dotyczące dopuszczalności sztucznego przerywania ciąży, to taki wynik wymuszać powinien dokonanie zmian ustawodawczych, czy to polegajacych na liberalizacji obowiązujących przepisów, czy ich zaostrzeniu. Sytuacja, która by w tym przypadku powstała, nie różniłaby się znacząco od tej, jaka pojawia się, gdy wynik jest pozytywny.

Rozważając problem następstw referendum ogólnokrajowego przynoszącego wiążący wynik, który jednak nie skłonił prawodawcy do ustanowienia aktu normatywnego zgodnego z tym wynikiem, warto się zastanowić nad możliwościa sięgnięcia do cywilnoprawnej instytucji odpowiedzialności Skarbu Państwa za szkody wynikające z powodu zaniechania legislacyjnego ${ }^{22}$.

Artykuł 67 o referendum nakłada bowiem na właściwe organy państwowe obowiązek podjęcia niezwłocznie czynności w celu realizacji wiążącego wyniku referendum zgodnie z jego rozstrzygnięciem. Dotyczyć to może m.in. organów dysponujących inicjatywą ustawodawcza, a także izb parlamentarnych.

Kwestię odpowiedzialności Skarbu Państwa za zaniechanie legislacyjne mające miejsce w interesującym nas przypadku należałoby jednak rozważyć oddzielnie i bardziej szczegółowo.

\section{IX}

Przyjmijmy jednak, że jeden z kompetentnych podmiotów wystapi z inicjatywą ustawodawczą mającą realizować pozytywny (negatywny) i wiążący wynik referendum ogólnokrajowego. Projekt stosownej ustawy wpłynie zatem do Sejmu. Czy jest to gwarancja, że zostanie w ogóle uchwalony lub uchwalony w zakładanym przez inicjatorów kształcie? W żadnym przypadku. Sejm może nie zdołać uchwalić ustawy wymaganej przez Konstytucję (art. 120) większością głosów. Posłowie i inne uprawione podmioty mogą wnieść do projektu ustawy poprawki zasadniczo zmieniające jej treść, a poprawki te mogą znaleźć uznanie Izby (art. 119 ust. 2). Może też mieć miejsce skuteczne zakwestionowanie przez Senat uchwalonej przez Sejm ustawy lub wprowadzenie do niej poprawek, których Sejm nie zdołał odrzucić (art. 121 ust. 2 i 3 Konstytucji RP). Wreszcie zdarzyć się może zgłoszenie weta przez Prezydenta RP i jego nieodrzucenie przez Sejm (art. 122 ust. 5). We wszystkich tych przypadkach wiążący wynik referendum nie zostanie zrealizowany lub będzie zrealizowany niezgodnie z wolą obywateli. Kwestia odpowiedzialności za taki bieg wydarzeń

${ }_{22}$ Por. Z. Banaszczyk, Odpowiedzialność za szkody wyrzqdzone przy wykonywaniu władzy publicznej, C. H. Beck, Warszawa 2012, s. 179 i n. 
pozostaje nierozstrzygnięta. Jak wskazywano już w literaturze, konstytucyjne i ustawowe przepisy dotyczace referendum ogólnokrajowego z art. 125 Konstytucji RP noszą wyraźne znamiona leges imperfectae $e^{23}$.

\section{$\mathbf{X}$}

Czy możliwe jest uniknięcie opisanych wyżej sytuacji? Nie jest to prawdopodobne na gruncie obowiązujących rozwiązań konstytucyjnych. Można jednak postulować de lege constitutionali ferenda rozwiązania alternatywne. Najbardziej skuteczne byłoby, moim zdaniem, przeniesienie na polski grunt tych pomysłów ustrojowych znanych w niektórych innych państwach, a mianowicie poddawanie rozstrzygnięciom referendalnym gotowych projektów ustaw. Pozytywny i wiążący wynik takich rozstrzygnięć byłby równoznaczny z uchwaleniem ustawy. Oznaczałoby to, w pewnym zakresie, podważenie dominacji parlamentu w dziedzinie ustawodawstwa i osłabienie zasady wyrażonej w art. 95 ust. 1 Konstytucji RP. By zminimalizować to niebezpieczeństwo, a także niebezpieczeństwo wykorzystywania narzędzia, jakim jest referendum, przeciw parlamentowi, prawo rozpisywania referendum ogólnokrajowego powinno pozostać w jego rękach (Sejmu lub Senatu, jako organu wyrażającego zgodę na referendum zarządzone z inicjatywy Prezydenta RP). Ponieważ jednak przyjęcie zaproponowanego tu rozwiązania grozić może tym, że w rezultacie referendum ogólnonarodowego do systemu prawa zostaną wprowadzone uregulowania niezgodne z Konstytucja lub ratyfikowanymi umowami międzynarodowymi, działania referendalne powinny być poddane kontroli ze strony Trybunału Konstytucyjnego ${ }^{24}$. Może to dotyczyć bądź projektu ustawy, która stać się ma ich przedmiotem, bądź ustawy uchwalonej w rezultacie ich przeprowadzenia.

Powyższa propozycja nie jest oryginalna nie tylko dlatego, że - jak wspomniałem - rozwiązanie takie znane jest w innych krajach, ale także dlatego, że odwołuje się w pewnym stopniu do tego, co przewiduje już polska Konstytucja. W jej art. 90 ust. 3 zawarte jest postanowienie, że w rezultacie wiążącego i pozytywnego wyniku referendum Prezydent RP otrzymuje zgodę na ratyfikację umowy międzynarodowej, o jakiej stanowi art. 90 ust. 1. Wynik ten zastępuje ustawę ratyfikacyjną z art. 90 ust. 2. Ustrojodawca dopuścił zatem w tym przypadku, że decyzja Narodu wyrażona w referendum nie wymaga „przełożenia” na ustawę; ma moc bezpośrednio obowiązująca. Jest to unormowanie trafne i okazało się skuteczne.

\footnotetext{
${ }^{23}$ Pogląd taki wyraża też L. Garlicki, op. cit., s. 14.

${ }_{24}$ Problem kontroli konstytucyjności referendum wywołuje jednak poważne kontrowersje. Louis Favoreau (we wstępie do książki Marthe Fatin-Rouge Stéfanini, op. cit.) podkreśla istnienie ,[...] le dilèmme entre pouvoirs du peuple et exigeances de l'Etat du droit. La question est déjà posée des lors qu'il s'agit de faire côntrole par la justice constitutionnelle une loi votee par le Parlement [...]. Mais la contestation est portée a son paroxisme si l'on envisage de soumettre une loi votée par le peuple a son examen du juge constitutionel” (s. 5-6).
} 
W tym miejscu przypomnieć też można dyskusje, które toczyły się wokół tych postanowień, przed referendum akcesyjnym do Unii Europejskiej w 2003 r. Chodziło mianowicie o to, czy gdyby referendum okazało się niewiążące, możliwy byłby powrót na droge procedur ustawowych. Zdania były w tym względzie podzielone. Uważam, że byłoby to możliwe, ponieważ referendum z wynikiem niewiążącym to referendum nieprzynoszące żadnego merytorycznego rozstrzygnięcia. Brak zaś rozstrzygnięcia cofa nas do stanu, o którym mowa w art. 90 ust. 2 Konstytucji RP. Gdyby przyjać, że również ustawy mogą być uchwalane w drodze referendum, brak wyniku wiążącego otwierałby danej sprawie drogę przed zwykłym postępowaniem ustawodawczym. Nie wchodziłaby tu bowiem w grę zasada ne bis in idem.

Wprowadzenie referendum, którego pozytywny i wiążący wynik jest równoznaczny z uchwaleniem ustawy, nie musi zamykać drogi do pozostawienia w mocy rozwiązań niewiążących się z takim skutkiem, tj. takich, w których celem głosowania referendalnego jest jedynie wybór jakiegoś ogólnego kierunku działań władz państwowych w danej sprawie (sprawach). Jednakże z istnieniem takiego referendum, jak wspominałem, może się łączyć szereg trudno rozwiązywalnych dylematów realizacyjnych.

\section{XI}

W literaturze poświęconej interesujacej nas problematyce pojawia się myśl, że celowe by było wprowadzenie do polskiego porządku ustrojowego, i to na poziomie ogólnokrajowym, instytucji recall na wzór tej, która od lat na stosunkowo znaczną skalę funkcjonuje na poziomie lokalnym i dotyczy powoływanych w wyborach bezpośrednich organów wykonawczych samorządu terytorialnego. Pogląd taki znajdujemy m.in. w artykule autorstwa Sabiny Grabowskiej, która analizuje przypadki islandzki i rumuński. Odwołuje się ona zarazem do stanowiska zajętego w tej kwestii przez Mariana Grzybowskiego, który w jednej ze swoich prac stwierdził, że ,jeśli prezydent został wybrany przez naród w wyborach bezpośrednich, to do obywateli powinna należeć decyzja o jego usunięciu"25. Procedura recall mogłaby w tym przypadku być składnikiem mechanizmu odpowiedzialności konstytucyjnej głowy państwa.

Nie sądzę, aby był to najszczęśliwszy pomysł. Jak wskazują polskie doświadczenia referendalne, postępowanie odwoławcze jest w przypadku wójtów, burmistrzów i prezydentów miast okazją do popisów demagogii politycznej i animozji, których źródła mają często niewiele wspólnego z obiektywną ocena pracy danych funkcjonariuszy. Okazuje się, że rozpisanie samorządowego referendum odwoławczego jest łatwiejsze niż referendum mającego przesądzać w sprawach merytorycznych. Gdyby instytucja recall miała dotyczyć głowy

${ }^{25}$ S. Grabowska, Referendum jako instytucja odpowiedzialności konstytucyjnej prezydenta $w$ Europie, w: „Przegląd Prawa i Administracji”, t. 87, 2012, s. 53 i n.; M. Grzybowski, Prawo wyborcze na urzad prezydenta Islandii, w: S. Grabowska, P. Grabowski (red.), Prawo wyborcze na urzad prezydenta w państwach europejskich, Warszawa 2007. 
państwa, zjawisko to przenieść się może na poziom ogólnokrajowy i przyczynić się do dewastacji życia publicznego. Twierdzę zatem, że istniejący mechanizm odpowiedzialności konstytucyjnej prezydenta jest wystarczający.

\section{XII}

Choć przeprowadzanie referendów ogólnokrajowych nie jest w Polsce częsta praktyka, to w ostatnich latach, zwłaszcza po 2010 r., pojawiło się kilka inicjatyw mających na celu ich rozpisanie. Istnieja, moim zdaniem, dwie główne przyczyny, które tłumaczą to zjawisko. Po pierwsze, obserwuje się spadek społecznego zaufania do instytucji przedstawicielskich, a przede wszystkim Sejmu. Stąd też rośnie nadzieja, że drogą referendalną będzie można osiagnąć cele, których realizacja nie wydaje się możliwa za pośrednictwem samych tych instytucji. Jeśli przedstawiciele Narodu nie chca, czy nie potrafią podjać ważnej społecznie decyzji, winien to uczynić sam suweren w głosowaniu powszechnym. Po drugie, inicjatywy referendalne podejmowane sa przez środowiska i ugrupowania polityczne opozycyjnie nastawione wobec aktualnej większości parlamentarnej i rządu będącego jej emanacją. Dosyć wyraźnym podtekstem takich inicjatyw, o czym już wspominałem, jest dążenie do zainicjowanie starcia politycznego, w nadziei, że doprowadzi ono do dezintegracji tej większości i upadku rządu. W każdym zaś razie do postawienia ich w trudnej sytuacji nawet wówczas, gdy do rozpisania referendum nie dojdzie, a może i z tego właśnie przede wszystkim powodu ${ }^{26}$.

Niewiele wskazuje, aby sytuacja ta uległa zmianie pod rzadami obecnie obowiązujących przepisów. Wśród przeszkód stojących na drodze upowszechnienia referendum ogólnokrajowego stoi i to, że warunkiem, od którego zależy jego wiążący wynik, jest osiagnięcie w głosowaniu frekwencji na poziomie ponad 50\% ogółu uprawnionych do uczestnictwa w tym akcie obywateli (art. 125 ust. 4 Konstytucji RP). Jak wiadomo, ich udział we wszelkich głosowaniach powszechnych jest w Polsce z reguły znacznie niższy. Nie postulowałbym jednak obniżenia wymogów frekwencyjnych wprowadzonych przez Konstytucję, ponieważ oddałoby się wówczas prawo decydowania w imieniu Narodu mniejszości, co znacznie osłabiłoby polityczną prawomocność referendów.

prof. dr hab. Piotr Winczorek

Uczelnia Eazarskiego $w$ Warszawie

em. profesor Uniwersytetu Warszawskiego

${ }^{26}$ Analizę motywów, które przyświecać mogą podmiotom rozpisującym referendum, zwłaszcza wówczas, gdy wchodzą one w skład elit politycznych kraju, zawiera: G. Rahat, Elite Motives for Initiating Referendums: Avoidance, Addition and Consideration, w: M. Sëtäla, T. Shiller (red.), op. cit., s. 98 i n. 


\section{SOME COMMENTS ON POLISH REFERENDA}

\section{Sum mary}

This paper contains the author's own opinions on the legal regulations governing a nationwide referendum referred to in Article 125 of the Constitution of the Republic of Poland. The basic framework of these regulations fits within the limits of standards applicable in democratic countries. Their exercise, however, may be obstructed due to the absence of effective institutional and procedural guarantees ensuring enforcement of a decision arrived at in a referendum. Obligatory organisation of a referendum initiated by citizens (conditioned on collection of a required number of supporters) is challenged, as well as the introduction to the Polish political regime of a recall option in respect of the head of state. A suggestion is also made that the premises for organising nationwide referenda provided for in the above mentioned article of the Constitution be precised, although without binding legal consequences. 
Copyright of Journal of Law, Economics and Sociology is the property of Faculty of Law and Administration of Adam Mickiewicz University in Poznan and its content may not be copied or emailed to multiple sites or posted to a listserv without the copyright holder's express written permission. However, users may print, download, or email articles for individual use.

Właścicielem praw autorskich do „Ruchu Prawniczego, Ekonomicznego i Socjologicznego” jest Wydział Prawa i Administracji Uniwersytetu im. Adama Mickiewicza w Poznaniu. Zawartość czasopisma nie może być kopiowana, przesyłana do innych stron internetowych bądź zamieszczana na blogach bez pisemnej zgody wydawcy. Niemniej artykuły można drukować, kopiować lub przesyłać w formie elektronicznej na własny użytek. 